\title{
Komparace nákladů na realizaci IPO na vybraných akciových trzích
}

\author{
Tomáš MELUZÍN, Brno University of Technology ${ }^{\mathrm{i}}$
}

\begin{abstract}
A company development funding through the Initial Public Offering has a high representation globally and belongs to traditional methods of fund raising necessary for development of business in developed capital markets. Also in the Central and Eastern European countries, including the Czech Republic, there can be found growing interest in this form of company financing. The objective of the article is to analyze the amount of costs related to an IPO launch on the main world security markets, and compare the same to the costs of IPO's launched on the Prague Stock Exchange during its modern history. To attain the objectives, research based on the collection of secondary and primary data was carried out. The results show us that the direct costs of IPO are reaching its minimum on the Euronext market, while the maximum is related to the HKSE market. Results also showed that the direct costs of IPO on the Czech capital market range between $5.6 \%$ and $9.0 \%$ of the value of issue. The biggest cost elements are underwriting fees, generating usually more than half of all direct IPO costs. The rest of direct IPO costs include fees due to professional advisors for audits, legal and other advisory services, costs of marketing and issuer's internal costs.
\end{abstract}

\section{Keywords}

Cost of IPO, Czech capital market, financing, IPO, world security market

JEL Classification: G32, D53, F37

\footnotetext{
${ }^{\mathrm{i}}$ Faculty of Business and Management, Brno University of Technology, Kolejní 4, 61200 Brno, Czech Republic. meluzint@fbm.vutbr.cz

The paper was written with the financial support of the Czech Science Foundation (Grant Agency of the Czech Republic), grant project No. 402/09/P134 Decision Model of Company Financing via IPO.
}

\section{1. Úvod a cíl práce}

Financování rozvoje společnosti prostřednictvím Initial Public Offering má ve světě velké zastoupení a na rozvinutých kapitálových trzích patří již $\mathrm{k}$ tradičním způsobům získávání peněžních prostředků potřebných pro rozvoj podnikání. Ve Spojených státech amerických, Japonsku a zemích západní Evropy je metoda financování podniků prostřednictvím IPO používána již po několik desetiletí. Prvotní veřejné nabídky akcií se začaly na těchto trzích ve větším počtu uplatňovat od začátku šedesátých let minulého století. Od té doby význam IPO ve světovém měřítku narůstá a v posledních letech se začínají veřejné nabídky akcií stále více využivat i v zemích střední a východní Evropy. Také v České republice lze od roku 2004 identifikovat několik společností, které přistoupily $\mathrm{k}$ této formě financování.

V odborné literatuře, např. Jenkinson a Ljungqvist (2001), Paleari a kol. (2006) a Welch (2006), lze nalézt celou řadu finančních i nefinančních důvodů pro vstup firmy na kapitálový trh formou IPO. Demonstrativně lze uvést např́ílad získání potřebných finančních zdrojů pro rozvoj společnosti bez omezení, která jsou spojena s úvěrovým financováním, zvýšení publicity a image firmy či omezení jedinečného rizika diverzifikací majetkového 
portfolia stávajícího vlastníka podniku. ${ }^{1} \mathrm{Z}$ výzkumu Meluzína (2008) vyplývá, že emitující společnosti obvykle vede $\mathrm{k}$ realizaci IPO kombinace několika důvodů. V současné době společnosti přistupují k této formě financování jak z důvodu získání potřebného kapitálu, tak i kvůli potřebě některých stávajících akcionářů (např. fondu rizikového kapitálu), kteří chtějí v rámci IPO odprodat své podíly ve společnosti. Při rozhodování o realizaci IPO je nutné brát v úvahu také skutečnost, že emise akcií na veřejných kapitálových trzích vyvolává na straně emitujícího podniku vznik celé řady nákladových položek.

Cílem článku je analyzovat velikost nákladů spojených s realizací IPO na hlavních světových akciových trzích a porovnat ji s náklady prvotních veřejných nabídek akcií, které byly realizovány na pražské burze v její novodobé historii. K dosažení stanoveného cíle byl proveden výzkum založený na sběru sekundárních i primárních dat. Zdrojem sekundárních dat byla jak tuzemská, tak zahraniční odborná literatura. Primární data byla získána na základě rozboru emisních prospektů a výročních zpráv emitujících společností a na základě konzultací s jejich představiteli. Při zpracování dané problematiky bylo použito zejména logických a empirických metod.

Článek je strukturován do tří částí. V první z nich jsou představeny výsledky komparativní analýzy zahraničních definicí pojmu IPO. Následující část se zabývá porovnáním nákladů na realizaci IPO na vybraných zahraničních trzích. Analýze byly podrobeny hlavní světové akciové trhy, tj. Deutsche Börse, London Stock Exchange (dále jen LSE), Euronext, New York Stock Exchange (dále jen NYSE), Nasdaq a Hong-Kong Stock Exchange (dále jen HKSE). Třetí část práce je věnována analýze nákladů spojených s realizací IPO na českém kapitálovém trhu, resp. pražské burze. V závěru jsou pak shrnuty nejzajímavější výsledky analýzy.

\section{Vymezení pojmu „Initial Public Offering“}

Při hledání relevantních definicí pojmu Initial Public Offering, pro který se všeobecně používá zkratka $I P O$, bylo využito zahraničních zdrojů, a to především ze Spojených států amerických a zemí západní Evropy.

- Americká SEC definuje IPO jako první veřejné vydáni akcii podnikem, který nebyl dosud veřejně obchodován.

\footnotetext{
1 Jedná se zejména o skutečnost, že kapitál získaný formou IPO nestaví společnost před často nepružný splátkový kalendář a využití peněžních prostředků není účelově vázáno.
}

- Nasdaq definuje IPO jako první prodej akcií soukromé společnosti veřejnosti.

- Podobné definice lze nalézt v pracích Welche (2006), který IPO definuje jako mechanismus, prostřednictvím něhož se poprvé dostávají akcie neveŕejně obchodovatelných společností $k$ běžným investorům.

- Autor Ritter (1998) ve své práci uvádí, že $I P O$ nastává v prípadě, kdy jsou cenné papiry poprvé prodány široké veřejnosti. Dle Rittera se přitom může jednat jak o majetkové cenné papíry (akcie), tak i o cenné papíry dluhového charakteru (obligace).

- V literatuře Ross, Westerfield a Jordan (1996) je IPO definována jako prvni veřejné vydání akcii, které souvisi s rozhodnutím firmy stát se veřejně obchodovatelnou společností.

- Dle Cartera a Manastera (1990) lze IPO definovat jako první nabídku akcii nebo obligací veřejnosti emitentem, jehož cenné papiry nebyly doposud kótovány na burze nebo podobném veřejném organizovaném trhu.

- Giudici, Vedove a Randone (2005) považují za IPO prvni umistěni cenných papirü, predevším akcií, na burzu.

- Khurshed (2000) definuje IPO jako první emisi cenných papiru pro širokou veřejnost nebo institucionálni investory firmou, která se zároveň kótuje na burze.

- Poradenská společnost Ernst \& Young (2008) pro účely svých analýz definuje IPO jako prvni nabidku podnikových akcií veřejnosti.

$Z$ výše uvedených definicí vyplývá, že většina autorů klade při vymezení tohoto pojmu důraz na skutečnost, že firma poprvé nabízí veřejnosti své cenné papíry, v užším slova smyslu akcie, a zároveň vstupuje na veřejný organizovaný trh cenných papírü ${ }^{2}$, představovaný nejčastěji burzou jakožto vrcholovou institucí. Podstatné je, že IPO může uskutečnit pouze emitent, $\mathrm{s}$ jehož cennými papíry se $\mathrm{v}$ dané době na veřejném trhu cenných papírů neobchoduje. Přitom většina autorů považuje za IPO i veřejnou nabídku cenných papírů společností, s jejichž cennými papíry se v minulosti na veřejném trhu obchodovalo, pokud

\footnotetext{
${ }^{2}$ Veřejný organizovaný trh $\mathrm{s}$ cennými papíry je $\mathrm{v}$ České republice podle zákona č. 256/2004 Sb., o podnikání na kapitálovém trhu, ve znění pozdějších předpisů, definován jako regulovaný trh s investičními nástroji.
} 
nová emise splňuje výše uvedené předpoklady pro IPO. ${ }^{3}$

Podle původu akcií nabízených v rámci IPO lze dle literatury Jenkinson a Ljungqvist (2001), Giudici, Vedove a Randone (2005), Huyghebaert a Hulle (2006) rozlišovat:

- IPO primárních ${ }^{4}$ akcií, při které dochází k emisi nových akcií a jejich uvedení na veřejný primární trh cenných papírů,

- IPO sekundárních ${ }^{5}$ akcií, spočívající v nabídce dřive vydaných akcií, se kterými se dosud obchodovalo pouze na neveřejném sekundárním trhu cenných papírů,

- kombinovanou IPO, při které se nově emitované akcie doplňují veřejnou nabídkou stávajících akcií.

Vzhledem k charakteru tohoto článku bude pojem Initial Public Offering dále používán v užším slova smyslu a IPO bude představovat zkratku pro prvotní veřejnou nabídku akcií.

\section{Analýza nákladů spojených s realizací IPO na zahraničních trzích}

Emise akcií na veřejných kapitálových trzích vyvolává na straně emitujícího podniku vznik celé řady nákladových položek. Ty lze obecně považovat za jednu z hlavních nevýhod této formy financování. Jak ukazuje obrázek 1 , náklady na IPO je možné rozdělit do dvou skupin, a to na:

- náklady na realizaci IPO,

- náklady spojené s veřejnou obchodovatelností akcií. ${ }^{6}$

\footnotetext{
${ }^{3}$ Někdy se ještě přihlíží $\mathrm{k}$ době mezi předchozí a novou kotací na burze. Např́iklad výzkumný tým S. Paleariho z Itálie nepovažuje za IPO veřejnou nabídku uskutečněnou společnostmi, s jejichž akciemi se přestalo na burze obchodovat $\mathrm{v}$ minulých pěti letech.

4 Zde je třeba upozornit na skutečnost, že v odborné literatuře neexistuje jednotná definice pojmu primární cenný papír. Např́klad v literatuře Rose (1992) a Rejnuš (2008) se za primární cenné papíry považují ty, které směřují přímo od emitenta ke konkrétnímu investorovi a jsou spojeny s tzv. přímým financováním.

5 Podobně jako je tomu u primárních cenných papírů, existují vodborné literatuře různé prrístupy $\mathrm{k}$ vymezení pojmu sekundární cenný papír. Např. v Rose (1992) a Rejnuš (2008) se za sekundární cenné papíry považují cenné papíry vydané finančním zprostředkovatelem a souvisí $\mathrm{s}$ tzv. nepř́mým financováním.

${ }^{6} \mathrm{~V}$ dalším textu bude pojednáno o nákladech na realizaci IPO, náklady spojené s veřejnou obchodovatelností akcií nebudou brány v úvahu.
}

Náklady na realizaci IPO zahrnují všechny př́mé i nepř́mé náklady, které jsou spojeny se samotným procesem prvotní veřejné nabídky akcií. Mezi přímé realizační náklady IPO patří především:

- poplatky upisovatelům ( $\mathrm{v}$ angl. označované jako gross spread),

- poplatky profesionálům za auditorské, právní a jiné poradenské služby,

- poplatky za přijetí akcií $\mathrm{k}$ obchodování na veřejných kapitálových trzích,

- náklady na marketingové aktivity (prezentaci společnosti potenciálním investorům),

- interní náklady emitující společnosti související s př́ípravou na IPO.

Za nepř́mý realizační náklad IPO je možné považovat podhodnocení emisního kurzu akcií, v angl. označované jako underpricing.

\subsection{Př́mé realizační náklady IPO}

Hodnotově nejvýznamnější položku přímých realizačních nákladů IPO obvykle představují poplatky upisovatelům. Ty jsou vanglicky psané literatuře nejčastěji označovány jako tzv. gross spread, který představuje rozdíl mezi cenou, za kterou upisovatel odkoupí akcie od emitenta, a emisním kurzem, za který jsou akcie poprvé nabízeny veřejnosti. Gross spread se nejčastěji vyjadřuje procentuálně z objemu emise (emisní kurz akcií násobený počtem nabízených akcií). Z Z výsledků empirických studií, které se zabývaly analýzou velikosti gross spreadu na jednotlivých akciových trzích, vyplývá, že na amerických trzích dosahuje vyšší hodnoty než na trzích evropských. Např́klad Torstila (2003) ve svém výzkumu dochází $\mathrm{k}$ závěrům, že:

- na amerických trzích dosahuje průměrná hodnota gross spreadu cca 7,5 \% a hodnota mediánu cca $7 \%$,

- na evropských trzích dosahuje průměrná hodnota gross spreadu cca 3,8 \% a hodnota mediánu cca $4 \%$.

Ritter (2007), který se zabývá studiem gross spreadu na amerických trzích v letech 1980-2006, uvádí, že většina amerických IPO je spojena s poplatky upisovatelům ve výši $7 \%$ z objemu emise. K podobným závěrům dochází i výzkum poradenské společnosti Oxera (2006), ve kterém byly analyzovány emise akcií uskutečněné na vybraných světových trzích v období od 1. 1. 2003 do 30. 6. 2005. Jak je patrné z tabulky 1, rozdíl mezi poplatky upisovatelům na amerických a evropských trzích činí přibližně tři procentní body. Pro emisi akcií v hodnotě 20 mil. GBP představují poplatky upisovatelům cca 700 tis. 


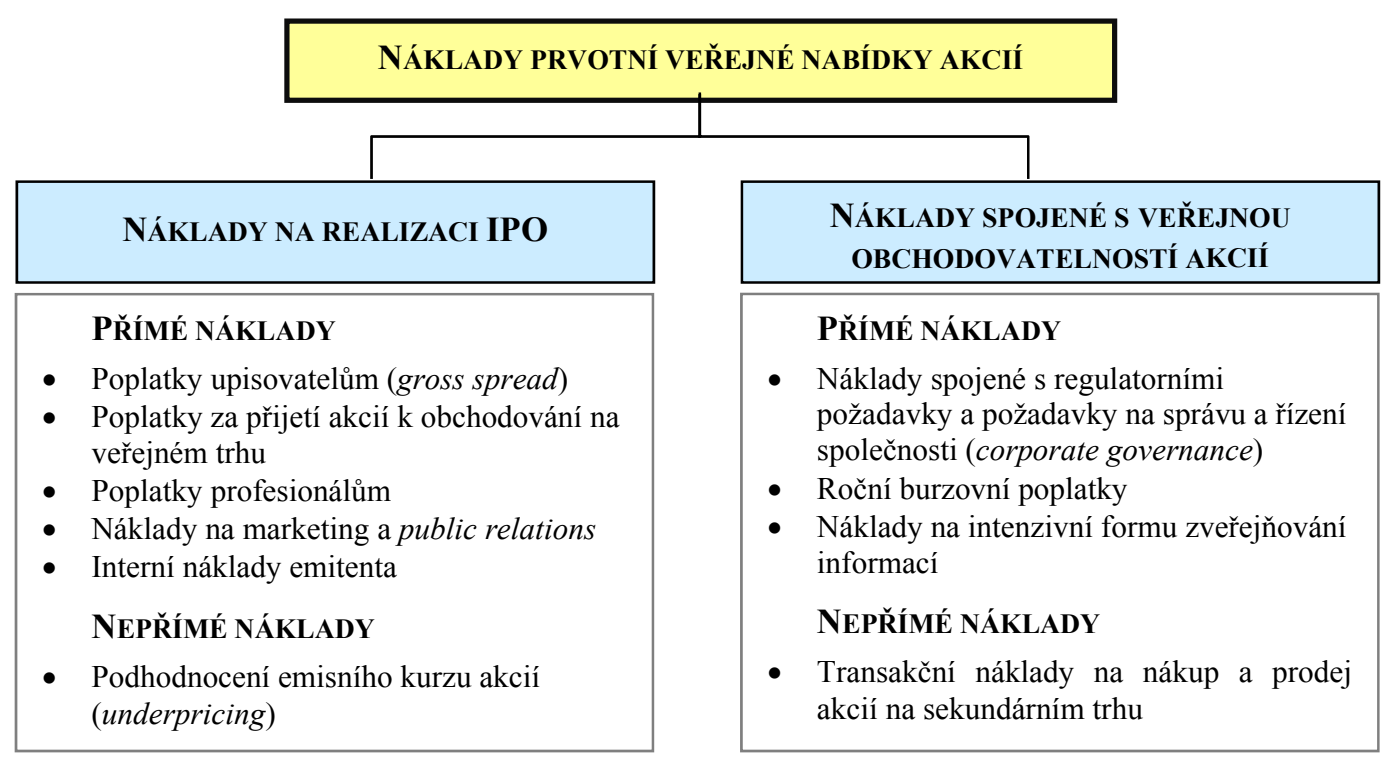

Obrázek 1 Náklady spojené s prvotní veřejnou nabídkou akcií Zdroj: vlastní zpracování dle lit. Oxera (2006)

GBP (tj. 3,5\% z objemu emise) na evropských trzích a cca 1,3 mil. GBP (tj. 6,5\% z objemu emise) na amerických trzích.

Mezi další realizační náklady IPO patří poplatky za prijetí akcií k obchodování na veřejných kapitálových trzích. Z uvedených studií vyplývá, že i když se jejich výše na jednotlivých trzích liší, nepřesahuje jejich velikost většinou $0,05 \% \mathrm{z}$ objemu emise. Lze tedy konstatovat, že v porovnání s poplatky upisovatelům představují poplatky za přijetí akcií $\mathrm{k}$ veřejnému obchodování pouze zanedbatelnou položku celkových nákladů IPO.

Zbývající část přímých realizačních nákladů IPO tvoří poplatky profesionálům za právní, auditorské a jiné poradenské služby, náklady na marketingové aktivity a interní náklady emitující společnosti související s přípravou IPO. Tyto náklady lze obvykle souhrnně kvantifikovat v rozmezí 3-6 \% z objemu emise. Je však třeba zdůraznit, že jejich skutečná výše je vždy individuální a závisí na specifikách jednotlivých emisí, např́klad na jejich velikosti a také na připravenosti emitenta pro vstup na kapitálový trh. Narozdíl od poplatků upisovatelům a poplatků za přijetí akcií k obchodování na veřejném trhu nejsou informace o těchto nákladech obvykle zveřejňovány, a je proto velmi obtížné je přesně vyčíslit.

\section{Komparace př́imých realizačních nákladů IPO na zahraničních trzích}

$\mathrm{Na}$ obrázku 2 je porovnána velikost mediánu a průměrné hodnoty pro celkové prrímé realizační náklady IPO na hlavních světových akciových trzích, tj. Deutsche Börse, LSE, Euronext, NYSE, Nasdaq a HKSE. Východiskem pro komparativní analýzu byla především studie Kaserer a Schiereck (2007), která se zabývala porovnáním nákladů na realizaci Deutsche Börse (7,9 \% z objemu emise). Nasdaq a LSE jsou spojeny $\mathrm{s}$ hodnotami mediánu pro prímé realizační náklady IPO ve výši 9,0 \%, resp. 9,9\% z objemu emise. Za nejdražší trh pro realizaci IPO je možné

Tabulka 1 Poplatky upisovatelům na vybraných světových trzích

\begin{tabular}{|l|c|c|c|c|}
\hline \multirow{2}{*}{ Burzovní trh } & \multicolumn{2}{|c|}{ Domácí společnosti } & \multicolumn{2}{c|}{ Zahraniční společnosti } \\
\cline { 2 - 5 } & Počet společností & Gross spread (\%) & Počet společností & Gross spread (\%) \\
\hline LSE - Main Market & 28 & 3,3 & 5 & 3,5 \\
\hline LSE - AIM & 43 & 3,5 & 8 & 4,9 \\
\hline NYSE & 74 & 6,5 & 14 & 5,6 \\
\hline Nasdaq & 192 & 7,0 & 28 & 7,0 \\
\hline Euronext & 7 & 1,8 & - & - \\
\hline Deutsche Börse & 6 & 3,0 & - & - \\
\hline
\end{tabular}

Zdroj: Oxera (2006) 
označit HKSE, nebot' medián př́mých realizačních nákladů IPO dosahuje 12,7 \% z objemu emise. Pokud budeme brát $\mathrm{v}$ úvahu průměrnou hodnotu prímých realizačních nákladů IPO, pořadí analyzovaných trhů se nezmění, avšak na trzích Euronext, NYSE a Deutsche Börse jsou rozdíly v získaných hodnotách jen velmi malé.

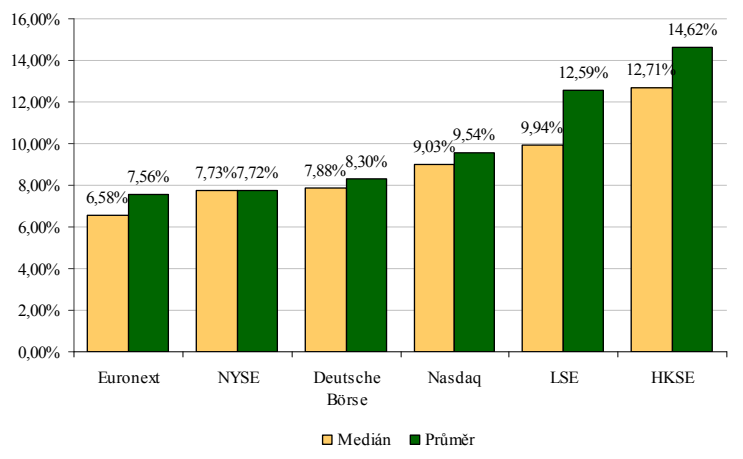

Obrázek 2 Porovnání přímých realizačních nákladů IPO na hlavních světových trzích

Zdroj: Kaserer a Schiereck (2007)

$\mathrm{V}$ př́padě porovnání nákladů na realizaci IPO je nutné upozornit na skutečnost, že jejich skutečná výše, vyjádřená relativně (v procentech z objemu emise), je vždy ovlivněna specifiky jednotlivých emisí, zejména jejich velikostí. Na obrázku 3 je proto zobrazena velikost př́mých realizačních nákladů IPO pro tržní segmenty velkých emisi (angl. large caps), jejichž tržní kapitalizace obvykle přesahuje 100 mil. EUR. Medián př́mých realizačních nákladů IPO dosahuje nejnižší hodnoty na tržním segmentu Eurolist $(5,4$ \% z objemu emise), po kterém následuje frankfurtský Prime/General Standard (6,6 \% z objemu emise).

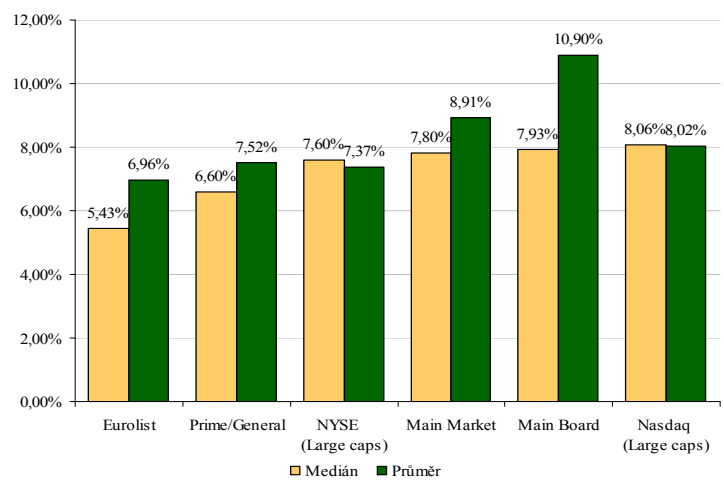

Obrázek 3 Porovnání př́mých realizačních nákladů IPO pro large caps na hlavních světových trzích

Zdroj: Kaserer a Schiereck (2007)

Následují další tržní segmenty analyzovaných akciových trhů $\mathrm{s}$ mediánem př́mých realizačních nákladů IPO v rozmezí 7,6-8,1\%. Z obrázku 3 dále vyplývá, že z hlediska průměrné hodnoty realizačních nákladů IPO je možné za nejdražší tržní segment označit Main Board na HKSE.

$\mathrm{Na}$ obrázku 4 je znázorněna velikost přímých realizačních nákladů IPO pro tržní segmenty malých emisí (v angl. small caps), jejichž objem většinou nepřesahuje 100 mil EUR. Medián př́mých realizačních nákladů IPO dosahuje nejnižší hodnoty na tržním segmentu Alternext (7,6 \% z objemu emise), po kterém následuje německý Entry Standard ( $8,2 \%$ $\mathrm{z}$ objemu emise). Americké trhy Nasdaq a NYSE jsou $\mathrm{v}$ př́ípadě small caps spojeny $\mathrm{s}$ realizačními náklady IPO ve výši 9,5\%, resp. 9,8\% z objemu emise. Dále následuje tržní segment londýnské burzy označovaný jako AIM, na kterém medián př́mých realizačních nákladů IPO dosahuje hodnoty $12,7 \%$ z objemu emise. Za nejdražší tržní segment pro small caps je možné označit GEM na HKSE (20,3 \% z objemu emise).

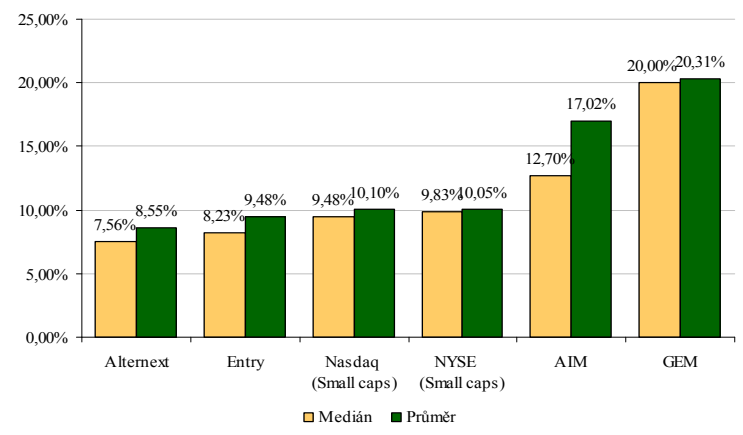

Obrázek 4 Porovnání přímých realizačních nákladů IPO pro small caps na hlavních světových trzích

Zdroj: Kaserer a Schiereck (2007)

Na obrázku 5 je znázorněna hodnota mediánu pro poplatky upisovatelům a ostatní přímé náklady na hlavních světových trzích. Poplatky upisovatelům představují největši přímý náklad IPO na trzích Deutsche Börse, NYSE, Euronext a Nasdaq. Ostatní přímé náklady spojené $\mathrm{s}$ realizací IPO dosahují nejnižší hodnoty na NYSE (1,2 \% z objemu emise).

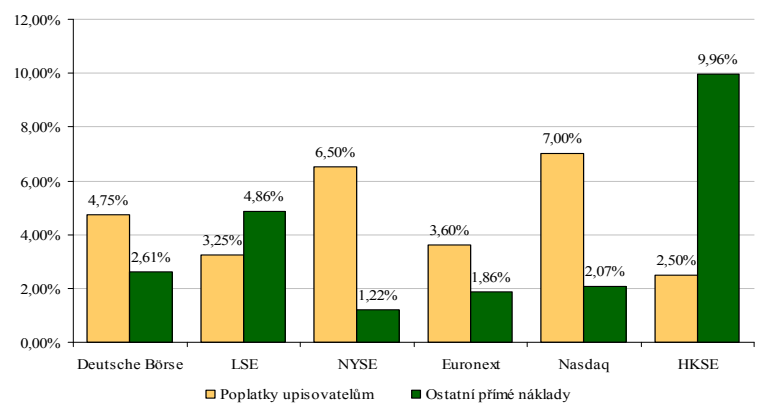

Obrázek 5 Velikost mediánu pro poplatky upisovatelům a ostatní přímé náklady na hlavních světových trzích Zdroj: Kaserer a Schiereck (2007) 
Euronext, Nasdaq a Deutsche Börse jsou spojeny $\mathrm{s}$ ostatními př́mými náklady kolem 2,0 \% z objemu emise. Na trzích LSE a HKSE dosahují tyto náklady nejvyšší hodnoty, na HKSE dokonce výrazně převyšují velikost poplatků upisovatelům.

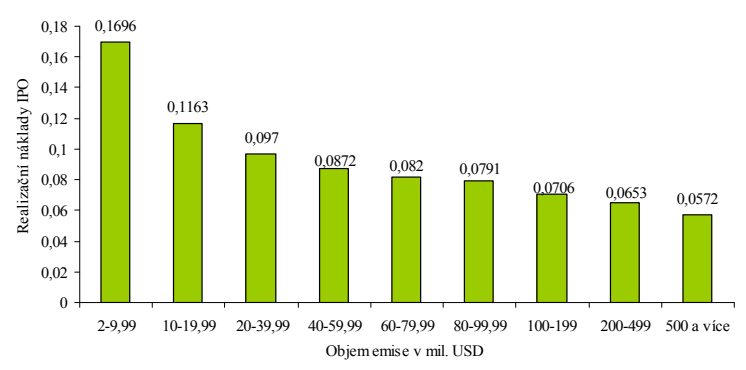

Obrázek 6 Realizační náklady IPO v závislosti na objemu emise na amerických trzích

Zdroj: Ritter (1998)

$\mathrm{Na}$ základě výsledků studie Oxera (2006) a Kaserer a Schiereck (2007) je možné konstatovat následující skutečnosti týkající se přímých realizačních nákladů IPO:

- Poplatky upisovatelům představují největší položku př́mých nákladů IPO. U většiny analyzovaných emisí jejich výše činila minimálně polovinu všech přímých nákladů IPO. Jejich rozdílná výše na amerických a evropských trzích má hlavní dopad na porovnání nákladnosti IPO na těchto trzích.

- Ostatní přímé náklady byly převážně rozloženy mezi poplatky finančním poradcům, právníkům a auditorům. Nelze však učinit jednoznačný závěr ohledně rozdílu v relativní výši právních, auditorských a poradenských služeb ani ostatních prrímých nákladů na amerických a evropských trzích.

- Pro společnosti, které realizují IPO na burzovních trzích mimo zemi jejich původu, mohou poplatky za právní a auditorské služby dosáhnout vyšší hodnoty než pro domácí společnosti. Je tomu tak především proto, že je nutné najmout právníky jak $\mathrm{v}$ zemi původu emitenta, tak i v zemi, kde se realizuje IPO, dále je nezbytné připravit finanční dokumentaci $\mathrm{v}$ jazyce a $\mathrm{v}$ souladu $\mathrm{s}$ účetními standardy příslušné země, v neposlední řadě jde též o nákladnější propagaci emitenta.

- Celkové přímé realizační náklady v relativním vyjádření ( $\mathrm{v}$ procentech $\mathrm{z}$ objemu emise) klesají se zvyšujícím se objemem emise. Je tomu tak $\mathrm{z}$ důvodu, že určitá část prímých realizačních nákladů (např. poplatky právním poradcům a auditorům, náklady na marketingové aktivity) je fixního charakteru.
Na obrázku 6 je znázorněna velikost přímých realizačních nákladů IPO v závislosti na objemu emise na amerických trzích.

\subsection{Underpricing - nepř́mý náklad IPO}

Empirické výzkumy, které se zabývají vývojem tržního kurzu akcií krátce po jejich prvotní veřejné nabídce, docházejí velmi často $\mathrm{k}$ závěru, že emitující společnosti nabízejí své akcie při IPO za nižší cenu, než za kterou se poprvé obchodují na sekundárním trhu. V anglicky psané literatuře se tato skutečnost označuje termínem underpricing, pro který je možné zavést český ekvivalent podhodnoceni emisního kurzu akcií. Vysvětlení, proč jsou emisní kurzy akcií při IPO obvykle podhodnoceny, jsou nejčastěji založeny na informační asymetrii mezi jednotlivými subjekty, které se účastní prvotní veřejné nabídky akcií.

Z pohledu emitenta představuje podhodnocení emisního kurzu akcií implicitní náklad IPO, nebot' společnost, resp. původní akcionáři (při nabídce sekundárních akcií) získávají méně peněžních prostředků. Pro vyjádření underpricingu existují dva přistupy. První z nich bere v úvahu pouze změnu mezi emisním kurzem a tržní cenou akcií na sekundárním trhu. Podhodnocení emisního kurzu akcií je možné $\mathrm{v}$ tomto prípadě vyjádřit pomocí následujícího vztahu:

$$
U=\frac{\left(P_{1}-P_{E}\right)}{P_{E}} \cdot 100,
$$

kde $U$ je podhodnocení emisního kurzu akcií (underpricing) v \%, $P_{1}$ je kurz akcie na konci prvního dne obchodování emise na sekundárním trhu a $P_{E}$ je emisní kurz akcie.

Pozn.: Pokud bude tržní kurz akcie $\left(P_{1}\right)$ nižší než její emisní kurz $\left(P_{E}\right)$, vyjde nám při výpočtu underpricingu $(U)$ záporná hodnota a lze konstatovat, že v daném případě byl emisní kurz nadhodnocen.

Vzhledem $\mathrm{k}$ tomu, že mezi stanovením emisního kurzu a začátkem obchodování emise na sekundárním trhu existuje vždy určitá časová prodleva, během které se akciové trhy vyvíjejí, lze při výpočtu underpricingu zohlednit změnu akciových kurzů. Underpricing upravený dle vývoje na akciovém trhu představuje druhý př́stup $\mathrm{k}$ jeho vyjádření. $\mathrm{K}$ jeho výpočtu lze použít následující vzorec:

$$
U_{M}=\left[\frac{\left(P_{1}-P_{E}\right)}{P_{E}}-\frac{M_{1}-M_{0}}{M_{0}}\right] \cdot 100,
$$

kde $U_{M}$ je underpricing po zohlednění vývoje tržního indexu $\mathrm{v} \%, M_{1}$ je hodnota tržního indexu na konci prvního dne obchodování emise na sekundárním trhu, 
Tabulka 2 Underpricing na vybraných akciových trzích v letech 2005-2006

\begin{tabular}{|c|c|c|c|c|c|c|c|c|c|c|}
\hline & \multicolumn{2}{|c|}{ Deutsche Börse } & \multicolumn{2}{|c|}{ Euronext } & \multicolumn{2}{|c|}{ HKSE } & \multicolumn{2}{|c|}{ LSE } & \multicolumn{2}{|c|}{ New York } \\
\hline $\begin{array}{c}\text { Tržní } \\
\text { segment }\end{array}$ & $\begin{array}{c}\text { Prime/ } \\
\text { General }\end{array}$ & Entry & Eurolist & Alternext & $\begin{array}{c}\text { Main } \\
\text { Board }\end{array}$ & GEM & $\begin{array}{c}\text { Main } \\
\text { Market }\end{array}$ & AIM & NYSE & Nas daq \\
\hline Vzorek & 42 & 36 & 53 & 52 & 74 & 8 & 49 & 362 & 78 & 207 \\
\hline \multicolumn{11}{|c|}{ Underpricing (v\%) } \\
\hline Průměr & 5,7 & 10,7 & 5,1 & 2,4 & 10,4 & 6,7 & 5,3 & 17,1 & 9,7 & 11,0 \\
\hline Medián & 2,2 & 0,3 & 3,6 & 0,0 & 6,3 & 2,6 & 2,9 & 9,4 & 5,5 & 6,6 \\
\hline Min & $-9,5$ & $-6,0$ & $-9,0$ & $-24,5$ & $-81,4$ & $-12,0$ & $-47,1$ & $-56,5$ & $-23,5$ & $-38,9$ \\
\hline $\operatorname{Max}$ & 25,7 & 100,0 & 23,0 & 44,0 & 88,6 & 30,7 & 25,7 & 350,0 & 120,8 & 140,5 \\
\hline \multicolumn{11}{|c|}{ Underpricing zohledňující vývoj tržního indexu (v\%) } \\
\hline Průměr & 5,7 & 10,8 & 5,1 & 2,3 & 10,5 & 7,1 & 5,1 & 17,0 & 9,6 & 11,0 \\
\hline Medián & 2,7 & 0,7 & 3,4 & 0,2 & 5,6 & 2,4 & 2,5 & 9,2 & 5,3 & 6,5 \\
\hline Min & $-8,5$ & $-5,8$ & $-8,2$ & $-24,8$ & $-80,1$ & $-11,7$ & $-47,3$ & $-56,7$ & $-24,7$ & $-38,5$ \\
\hline Max & 26,3 & 99,3 & 22,9 & 43,4 & 89,4 & 32,2 & 25,5 & 350,2 & 120,8 & 140,6 \\
\hline
\end{tabular}

Zdroj: Kaserer a Schiereck (2007)

$M_{0}$ je hodnota tržního indexu na konci dne předcházejícího prvnímu dni obchodování emise na sekundárním trhu.

$\mathrm{V}$ tabulce 2 je vyjádřena velikost underpricingu na vybraných akciových trzích v letech 2005-2006, z čehož vyplývají dva zajímavé poznatky. Zaprvé, rozdíl mezi výpočtem underpricingu bez zohlednění tržního indexu dle (1) a s jeho zohledněním dle (2) je zanedbatelný. Zadruhé, velikost počáteční výnosnosti akcií, resp. underpricingu je na jednotlivých trzích značně rozdílná. Hlavní vliv na výši underpricingu má dle empirických výzkumů zejména velikost a stáří emitujících společností.

$\mathrm{V}$ tabulce 3 je uveden underpricing amerických IPO a celková hodnota implicitního nákladu, který emitentům vznikl v souvislosti s podhodnocením emisního kurzu akcií v letech 1990-2006.

\section{Analýza nákladů spojených s realizací IPO na českém kapitálovém trhu}

V podmínkách českého kapitálového trhu není zatím příliš obvyklé financování rozvoje společnosti prostřednictvím prvotní veřejné nabídky akcií. V novodobé historii českého kapitálového trhu, resp. pražské burzy, lze teprve od roku 2004 identifikovat několik společností, které přistoupily $\mathrm{k}$ této formě financování. Tyto společnosti se staly předmětem výzkumu, jehož cílem bylo určit výši nákladů spojených s realizací IPO na českém kapitálovém trhu. K dosažení stanoveného cíle byly analyzovány emisní prospekty a výroční zprávy emitujících společností a byl uskutečněn kvalitativní výzkum emitujících společností formou osobního setkání s jejich představiteli.
Přehled vybraných charakteristik prvotních veřejných nabídek akcií, které se uskutečnily na českém kapitálovém trhu v letech 2004-2008, je uveden v tabulce 4. Následuje stručný popis emitujících společností a zhodnocení získaných výsledků. Společnosti jsou uvedeny chronologicky dle jejich vstupu na český kapitálový trh.

Tabulka 3 Underpricing a celkový implicitní náklad IPO v USA v letech 1990-2006

\begin{tabular}{|c|c|c|c|}
\hline Rok & $\begin{array}{c}\text { Počet } \\
\text { IPO }\end{array}$ & Underpricing & $\begin{array}{c}\text { Celkový } \\
\text { implicitní } \\
\text { náklad IPO } \\
\text { (mld. USD) }\end{array}$ \\
\hline 1990 & 107 & $10,9 \%$ & 0,30 \\
\hline 1991 & 278 & $11,9 \%$ & 1,36 \\
\hline 1992 & 392 & $10,3 \%$ & 1,73 \\
\hline 1993 & 487 & $12,8 \%$ & 3,24 \\
\hline 1994 & 405 & $9,8 \%$ & 1,47 \\
\hline 1995 & 457 & $21,1 \%$ & 4,76 \\
\hline 1996 & 672 & $17,2 \%$ & 6,80 \\
\hline 1997 & 472 & $13,9 \%$ & 4,53 \\
\hline 1998 & 283 & $21,7 \%$ & 5,25 \\
\hline 1999 & 476 & $71,0 \%$ & 36,94 \\
\hline 2000 & 380 & $56,3 \%$ & 29,67 \\
\hline 2001 & 80 & $13,9 \%$ & 2,97 \\
\hline 2002 & 66 & $9,1 \%$ & 1,13 \\
\hline 2003 & 63 & $12,2 \%$ & 1,01 \\
\hline 2004 & 174 & $12,3 \%$ & 3,83 \\
\hline 2005 & 161 & $10,0 \%$ & 2,65 \\
\hline 2006 & 158 & $12,3 \%$ & 3,97 \\
\hline $\mathbf{1 9 9 0 - 2 0 0 6}$ & $\mathbf{5 1 1 1}$ & $\mathbf{2 2 , 7} \%$ & $\mathbf{1 1 1 , 6}$ \\
\hline$Z 12 \%$ & & \\
\hline
\end{tabular}

Zdroj: Ritter (2007)

Za první společnost, která na českém kapitálovém trhu uskutečnila IPO, je obvykle označována Zentiva, $N . V$. (dále jen Zentiva). Pro přesnost je však nutné uvést, že Zentiva představuje první společnost, která 
uskutečnila IPO na pražské burze ${ }^{7}$. Společnost Zentiva je mezinárodní farmaceutickou společností se zaměřením na vývoj, výrobu a prodej moderních značkových generických farmaceutických př́pravků. Akcie firmy Zentiva byly v červnu roku 2004 kótovány na pražské burze a ve formě globálních depozitních akcii ${ }^{8}$ na londýnské burze. Celková velikost IPO činila cca 174,9 mil. EUR, a hrubý výnos společnosti cca 65,85 mil. EUR. Celkové přímé náklady prvotní veřejné nabídky akcií společnosti Zentiva činily cca $6,6 \%$ z objemu emise. Největší část těchto nákladů představovaly poplatky upisovatelům, které činily $4 \%$ z objemu emise. Zbývající část př́mých nákladů, tedy cca $2,6 \%$, tvořily poplatky právním poradcům a finančním auditorům, dále pak náklady na marketing a interní náklady společnosti. Čistý výnos společnosti, který byl použit zejména na snížení jejího zadlužení a další akvizice, představoval dle provedených výpočtů cca 58,67 mil. EUR. Nepř́mý náklad IPO, který je spojen $\mathrm{s}$ tzv. podhodnocením emisního kurzu akcií, činil cca $4,02 \%$ z objemu emise ${ }^{9}$.

Po více než dvou letech od uskutečnění IPO Zentivy byly na pražské burze v prosinci roku 2006 realizovány další dvě prvotní veřejné nabídky akcií. První z nich uskutečnila společnost ECM Real Estate Investments, A.G. (dále jen ECM). Jedná se o holdingovou společnost skupiny zabývající se developerskou a investiční činností v oblasti nemovitostí. Celková velikost IPO činila cca 80,72 mil. EUR a hrubý výnos společnosti cca 65,92 mil. EUR. Hlavní část př́mých nákladů IPO představovaly poplatky upisovatelům, jejichž výše činila $5 \%$ z objemu emise. Ostatní př́mé náklady byly dle provedených výpočtů odhadnuty na výši cca 1,86 \% $\mathrm{Z}$ velikosti emise. Celkové prrímé náklady spojené $\mathrm{s}$ prvotní veřejnou nabídkou akcií společnosti ECM tak představují cca $6,86 \% \mathrm{z}$ objemu emise. Toto číslo a na základě něho provedené další výpočty je však nutné brát jako orientační, nebot' přesnou výši ostatních prímých nákladů spojených $\mathrm{s}$ IPO si společnost ECM neprála zveřejnit. Čistý výnos společnosti, který byl použit na její rozvoj, činil cca 61,12 mil. EUR. Nepř́mý náklad IPO, tzv. underpricing, byl, v porovnání s ostatními IPO

\footnotetext{
${ }^{7}$ V novodobé historii českého kapitálového trhu realizovala první IPO společnost Software 602, a.s., s jejímiž akciemi se však, vzhledem k velmi malé tržní kapitalizaci emise (20 mil. Kč), obchodovalo pouze na mimoburzovním trhu, RMSystému, a.s.

${ }^{8}$ V angl. označované jaké Global Depositary Shares (GDS).

${ }^{9}$ Při výpočtu podhodnocení emisního kurzu akcií bylo u IPO realizovaných na českém kapitálovém trhu použito vzorce (1-1), tj. nebyl zohledněn vývoj tržního indexu.
}

realizovanými na českém kapitálovém trhu, relativně vysoký, nebot' činil cca 11,7 \% z objemu emise.

Dalším úspěšným emitentem, který na český kapitálový trh vstoupil téměř souběžně se společností ECM, byla společnost Pegas Nonwovens, S.A. (dále jen Pegas). Pegas je jedním z předních evropských výrobců netkaných textilií používaných zejména na trhu osobních hygienických výrobků. Akcie společnosti Pegas byly v prosinci roku 2006 přijaty k obchodování na pražské a varšavské burze cenných papírů. Celková velikost IPO činila přes 136 mil. EUR a hrubý výnos společnosti cca 48,87 mil. EUR. Hlavní část př́mých nákladů IPO představovaly, podobně jako $\mathrm{v}$ př́padě předchozích prvotních veřejných nabídek, poplatky upisovatelům. Jejich výše činila $3,50 \%$ z objemu emise. Ostatní přímé náklady byly dle provedených výpočtů odhadnuty na výši cca 3,78 $\%$ z velikosti emise. Celkové prímé náklady prvotní veřejné nabídky akcií společnosti Pegas tak činily cca $7,28 \%$ z objemu emise. Stejně jako u předchozího emitenta je toto číslo a na jeho základě provedené další výpočty nutné brát pouze jako orientační. Přesnou výši ostatních př́mých nákladů spojených s IPO si společnost Pegas nepřála zveřejnit. Čistý výnos společnosti, který byl použit zejména na snížení jejího zadlužení, činil cca 42 mil. EUR. Nepřímý náklad IPO, který je spojen s podhodnocením emisního kurzu akcií, činil cca 4,53 \% z objemu emise.

V druhé polovině roku 2007 se na českém kapitálovém trhu, přes počínající hypoteční krizi a s tím související nejistotu na finančních trzích, uskutečnily další dvě prvotní veřejní nabídky akcií. První z nich uskutečnila společnost AAA Auto Group, N.V. (dále jen AAA Auto). Tato společnost představuje jednoho $\mathrm{z}$ největších maloobchodních prodejců motorových vozidel a zprostředkovatelů finančních služeb se zaměřením na motorová vozidla na trzích střední a východní Evropy. Akcie společnosti AAA Auto byly v záŕí roku 2007 prijaty k obchodování na pražské a budapešt'ské burze.

Celková velikost IPO činila cca 35,5 mil. EUR. Tato částka zároveň představovala hrubý výnos společnosti. Celkové prrímé náklady prvotní veřejné nabídky akcií společnosti AAA Auto činily cca $6,76 \%$ z objemu emise. Největší nákladovou položku činily poplatky upisovatelům $(2,96 \quad \% \quad$ z objemu emise), dále pak poplatky právním poradcům $(1,16 \%$ z objemu emise), interní a personální náklady spojené s IPO $(1,05 \%$ z objemu emise), poplatky auditorům $(0,72 \%$ z objemu emise), náklady na marketing a public relations $(0,69 \%$ z objemu emise). Ostatní př́mé náklady IPO činily cca $0,18 \%$ z objemu emise. Čistý výnos společnosti, který byl použit zejména na její další rozvoj, představoval cca 33,1 mil. EUR. 
Tabulka 4 Vybrané charakteristiky IPO na českém kapitálovém trhu

\begin{tabular}{|l|c|c|c|}
\hline \multirow{2}{*}{ Charakteristika IPO } & \multicolumn{3}{c|}{ Emitující společnost } \\
\cline { 2 - 4 } & ZENTIVA & ECM & PEGAS \\
\hline \hline Datum uskutečnění IPO & 28.6 .2004 & 7.12 .2006 & 18.12 .2006 \\
\hline \hline Celkový počet upsaných akcí (ks) & 11500000,00 & 1717530,00 & 5042750,00 \\
\hline z toho primární akcie (ks) & 4329896,00 & 1402500,00 & 1810000,00 \\
\hline \hline Emisní kurz (EUR / akcie) & 15,21 & 47,00 & 27,00 \\
\hline \hline Velikost emise (EUR) & 174898087,00 & 80723910,00 & 136154250,00 \\
\hline \hline Hrubý výnos společnosti (EUR) & 65851350,00 & 65917500,00 & 48870000,00 \\
\hline \hline Náklady IPO (EUR) & & & 4766000,00 \\
\hline poplatky & 6995923,00 & 4036196,00 & 5150000,00 \\
\hline ostatní př́mé náklady & 4546879,00 & 1500000,00 & 9916000,00 \\
\hline celkem & 11542802,00 & 5536196,00 & \\
\hline \hline Náklady IPO (\% z velikosti emise) & & & $3,50 \%$ \\
\hline poplatky & $4,00 \%$ & $5,00 \%$ & $3,78 \%$ \\
\hline ostatní př́mé náklady & $2,60 \%$ & $1,86 \%$ & $7,28 \%$ \\
\hline celkem & $6,60 \%$ & $6,86 \%$ & $42 \% 000000,00$ \\
\hline \hline Čistý výnos společnosti (EUR) & 58670429,00 & 61119875,00 & 28,22 \\
\hline \hline $\begin{array}{l}\text { Závěrečný kurz 1. dne obchodování (EUR/ } \\
\text { akcie) }\end{array}$ & 15,82 & 52,50 & $4,53 \%$ \\
\hline \hline Underpricing & $4,02 \%$ & $11,70 \%$ & \\
\hline
\end{tabular}

\begin{tabular}{|l|c|c|c|}
\hline \multirow{2}{*}{ Charakteristika IPO } & \multicolumn{2}{c|}{ Emitující společnost } \\
\cline { 2 - 4 } & AAA & VGP & NWR \\
\hline \hline Datum uskutečnění IPO & 24.9 .2007 & 7.12 .2007 & 6.5 .2008 \\
\hline Celkový počet upsaných akcií (ks) & 17757875,00 & 3583050,00 & 95465345,00 \\
\hline z toho primární akcie (ks) & 17757875,00 & 3583050,00 & 13500000,00 \\
\hline \hline Emisní kurz (EUR / akcie) & 2,00 & 15,25 & 16,56 \\
\hline Velikost emise (EUR) & 35515750,00 & 54641512,50 & 1581144776,00 \\
\hline \hline Hrubý výnos společnosti (EUR) & 35515750,00 & 54641512,00 & 223593750,00 \\
\hline \hline Náklady IPO (EUR) & & & - \\
\hline poplatky upisovatelùm & 1052379,00 & - & 47434343,00 \\
\hline ostatní př́mé náklady & 1347621,00 & & 41218448,00 \\
\hline celkem & 2400000,00 & 4917736,00 & 88652791,00 \\
\hline Náklady IPO (\% z velikosti emise) & & & - \\
\hline poplatky upisovatelům & $2,96 \%$ & - & $3,00 \%$ \\
\hline ostatní přímé náklady & $3,79 \%$ & $9,76 \%$ & $2,61 \%$ \\
\hline celkem & 33115750,00 & 49723776,00 & 175667488,00 \\
\hline \hline Čistý výnos společnosti (EUR) & 2,00 & 15,60 & 17,81 \\
\hline $\begin{array}{l}\text { Závěrečný kurz 1. dne obchodování (EUR / } \\
\text { akcie) }\end{array}$ & $0,05 \%$ & $2,30 \%$ & $7,55 \%$ \\
\hline Underpricing & & & $5,61 \%$ \\
\hline
\end{tabular}

Zdroj: vlastní zpracování 
Nepř́mý náklad IPO, spojený s podhodnocením emisního kurzu akcií, byl zanedbatelný (cca 0,05 \% $\mathrm{z}$ objemu emise).

Druhou emitující společností v roce 2007 byla společnost $V G P, N . V$. (dále jen VGP). Jedná se o realitní skupinu se specializací na akvizice, developement a správu semiindustriálních objektů. $\mathrm{Na}$ sklonku roku 2007 uskutečnila společnost VGP svoji prvotní veřejnou nabídku akcií na pražské burze. Velikost IPO, resp. hrubý výnos společnosti, činil cca 54,64 mil. EUR. Celkové př́mé náklady prvotní veřejné nabídky akcií společnosti VGP činily cca $9 \%$ z objemu emise, konkrétní strukturu těchto nákladů si však společnost nepřála zveřejnit. Čistý výnos společnosti, který byl použit $\mathrm{k}$ financování jejích podnikatelských aktivit, přestavoval dle provedených výpočtů cca 49,72 mil. EUR. Neprímý náklad IPO, tzv. underpricing, činil cca 2,30 \% z objemu emise.

$\mathrm{K}$ datu zpracování tohoto př́spěvku představuje poslední společnost, která na českém kapitálovém trhu uskutečnila IPO, New World Resources, N.V. (dále jen NWR). Emitent je prostřednictvím své dceřiné společnosti OKD, a.s., největší společností těžící černé uhlí a předním producentem černého uhlí v České republice a v geografickém regionu Střední Evropy. Akcie společnosti NWR byly v květnu roku 2008 přijaty k obchodování na pražské, varšavské a londýnské burze. Celková velikost IPO činila cca 1,58 mld. EUR, a lze tak hovořit o doposud největší IPO v novodobé historii pražské burzy. Hrubý výnos společnosti činil cca 223,6 mil. EUR. Celkové přímé náklady prvotní veřejné nabídky akcií společnosti NWR činily cca 5,61 \% z objemu emise. Největší část těchto nákladů představovaly poplatky upisovatelům, které činily $3 \%$ z objemu emise. Čistý výnos společnosti, který byl použit $\mathrm{k}$ financování jejího dalšího rozvoje, představoval dle provedených výpočtů cca 175,67 mil. EUR. Nepř́mý náklad IPO, související s podhodnocením emisního kurzu akcií během jejich první veřejné nabídky, činil cca 7,55 \% z objemu emise.

Pokud se týká finančních aspektů realizace IPO, dotazované podniky se shodují na tom, že prvotní veřejná nabídka akcií je spojena s vysokými výdaji za externí poradce, za interní lidské zdroje a za procesy ve firmě. Emitenti zdůrazňují, že celkové náklady na IPO, které jsou obvykle vyjádřeny procentuelně z objemu emise, nepředstavují jednorázově vynaloženou odměnu za získání potřebných finančních zdrojů, jako je tomu v př́ípadě úvěrového financování. Emitující společnosti $v$ souladu se zmíněnými teoretickými př́stupy uvedly, že za hlavní nákladové položky realizace IPO je nutné považovat poplatky manažerovi emise, právním poradcům a finančním auditorům, dále pak poplatky za prrijetí akcií k obchodování na burzovním trhu, poplatky regulatorním orgánům a náklady spojené s prezentací IPO investorům, včetně tzv. road show. Další výdaje je nutné vynaložit na zavedení nových procesů v podniku, které jsou spojeny zejména s plněním pravidelné informační povinnosti stanovené pro společnosti, s jejichž cennými papíry se obchoduje na veřejném kapitálovém trhu.

K problematice podhodnocení emisního kurzu akcií manažěri uvádějí, že možnost realizace nadprůměrně vysokých zisků během prvního dne obchodování s akciemi na sekundárním trhu přitahuje zájem médií a zvyšuje publicitu emitenta. Underpricing byl $\mathrm{v}$ jejich př́padě vnímán spíše jako nástroj ke zvýšení pravděpodobnosti úspěchu IPO než náklad IPO. Je tedy možné konstatovat, že i když je underpricing teoreticky považován za významný nepřímý náklad IPO, snaha o jeho účelné snižování nemusí stát vždy v popředí zájmu emitentů.

Na základě provedené analýzy prvotních veřejných nabídek akcií, které byly dosud ${ }^{10}$ realizovány na českém kapitálovém trhu, lze konstatovat následující skutečnosti:

- IPO uskutečnily výhradně nadnárodní podniky holdingového typu, které provozují svoji podnikatelskou činnost na území České republiky, jejich mateřská společnost však má sídlo v zahraničí, a to $\mathrm{v} z e m i$, ve které jsou společnosti zvyklé využívat kapitálový trh pro získání potřebných finančních zdrojů.

- Většina prvotních veřejných nabídek akcií měla charakter kombinované IPO, v rámci které byly investorům nabídnuty jak primární, tak sekundární akcie. Čistý výnos emitentů byl využit $\mathrm{k}$ jejich rozvoji a splacení dluhů.

- Velikost emise byla velmi rozdílná, minimální hodnota činila 35,5 mil. EUR, maximální hodnota 1,58 mld. EUR a medián 108,44 mil. EUR.

- Celkové př́mé náklady IPO činily cca 5,69,0 \% z objemu emise. Největší nákladovou položku představovaly poplatky manažerovi emise, které se pohybovaly v rozmezí 2,96$5,0 \%$ z objemu emise, zbývají část pak tvořily poplatky právním poradcům a finančním auditorům, náklady na marketing a interní náklady společnosti.

- Nelze učinit jednoznačný závěr ohledně výše podhodnocení emisního kurzu akcií, který je označován za nepřímý náklad IPO. Z výzkumu vyplývá, že existence underpricingu může být

\footnotetext{
${ }^{10}$ Stav k 1. 6. 2009.
} 
vnímána i jako přínos pro emitující společnosti, napřr. v podobě nástroje ke zvýšení pravděpodobnosti úspěchu IPO. Jeho účelné snižování tak nemusí být vždy v popředí zájmu emitentů.

\section{Závěr}

Z dosažených výsledků vyplývá, že největší položku př́mých realizačních nákladů IPO obvykle představují poplatky upisovatelům. Na většině analyzovaných trzích jejich výše činila více jak polovinu všech př́mých realizačních nákladů IPO. Vzhledem $\mathrm{k}$ tomu, že rozdíl mezi poplatky upisovatelům na amerických a evropských trzích činí přibližně tři procentní body, má jejich rozdílná výše hlavní dopad na porovnání nákladnosti IPO na těchto trzích.

Z hlediska mediánu dosahují prímé realizační náklady IPO nejnižší hodnoty na trhu Euronext (6,6 \% z objemu emise), po kterém následují trhy NYSE $(7,7 \%$ z objemu emise) a Deutsche Börse (7,9 \% z objemu emise). Nasdaq a LSE jsou spojeny $\mathrm{s}$ hodnotami mediánu pro př́mé realizační náklady IPO ve výši 9,0\%, resp. 9,9 \% z objemu emise. Za nejdražší trh pro realizaci IPO je možné označit HKSE, nebot' medián př́mých realizačních nákladů IPO dosahuje $12,7 \%$ z objemu emise.

Pro všechny analyzované trhy platí, že se zvyšujícím se objemem emise prímé realizační náklady IPO $\mathrm{v}$ absolutní výši rostou, v relativním vyjádřrení (v procentech z objemu emise) však klesají.

Za nepřímý realizační náklad IPO je považován underpricing, neboli podhodnocení emisního kurzu akcií. Z dosažených výsledků vyplývá, že jeho výše je na jednotlivých trzích značně rozdílná (průměrná hodnota dosahuje od 2,4 do 17,1 \% z objemu emise). Hlavní vliv na výši underpricingu má dle empirických výzkumů zejména velikost a stáří emitující společnosti.

Na základě provedené analýzy prvotních veřejných nabídek akcií, které byly realizovány na českém kapitálovém trhu, lze konstatovat, že celkové přímé náklady IPO činily cca 5,6-9,0 \% z objemu emise. Největší nákladovou položku představovaly poplatky manažerovi emise, které se pohybovaly $\mathrm{v}$ rozmezí 2,96-5,0 \% z objemu emise, zbývající část pak tvořily poplatky právním poradcům a finančním auditorům, náklady na marketing a interní náklady společnosti.

Pokud se týká nepř́mého nákladu IPO, tj. podhodnocení emisního kurzu akcií, nelze učinit jednoznačný závěr o jeho velikosti v českých podmínkách. Z dosažených výsledků vyplývá, že i když je underpricing teoreticky považován za významný nepř́imý náklad IPO, snaha o jeho účelné snižování nemusí stát vždy v popředí zájmu emitentů.
Možnost realizace nadprůměrně vysokých zisků během prvního dne obchodování s akciemi na sekundárním trhu přitahuje zájem médií a zvyšuje publicitu emitenta. Underpricing byl proto vnímán spíše jako nástroj ke zvýšení pravděpodobnosti úspěchu IPO než náklad IPO.

\section{Literatura}

CARTER, R.B., MANASTER, S. (1990). Initial Public Offering and Underwriter Reputation. Journal of Finance 45 (4): 1045-1067.

http://dx.doi.org/10.2307/2328714

GIUDICI, G., VEDOVE, F.D., RANDONE, P.A. (2005). The evolution of Initial Public Offerings in Italy. BItNotes 14: 1-35.

HUYGHEBAERT, N., VAN HULLE, C. (2006). Structuring the IPO: Empirical evidence on the portions of primary and secondary shares. Journal of Corporate Finance 12: 296-320.

http://dx.doi.org/10.1016/j.jcorpfin.2005.01.001

JENKINSON, T., LJUNGQVIST, A. (2001). Going Public: The Theory and Evidence on How Companies Raise Equity Finance. Oxford: Oxford University Press.

KHURSHED, A. (2000). Discussion of Does the Presence of Venture Capitalists Improve the Survival Profile of IPO firms? Journal of Business Finance \& Accounting 27 (9): 1177-1183.

http://dx.doi.org/10.1111/1468-5957.00351

MELUZÍN, T. (2008). Komparace teoretických a praktických př́stupů $\mathrm{k}$ financování formou IPO na českém kapitálovém trhu. Acta Universitatis Agriculturae et Silviculturae Mendelianae Brunensis 56 (6): 59-68.

PALEARI, S. a kol. (2006). Academic EurIPO Fact Book 2006. Bergamo: Universoft.

REJNUŠ, O. (2008). Finančni trhy. Ostrava: KEY Publishing.

RITTER, J.R. (1998). Initial Public Offerings. Contemporary Finance Digest 2 (1): 5-30.

ROSE, P.S. (1992). Money and capital markets, 4th edition. Boston: IRWIN.

ROSS, S.A., WESTERFIELD, R.W., JORDAN, B.D. (1996). Essentials of Corporate Finance. Boston: McGraw-Hill.

TORSTILA, S. (2003). The Clustering of IPO Gross Spreads: International Evidence. Journal of Financial and Quantitative Analysis 38 (3): 673-694.

http://dx.doi.org/10.2307/4126736 


\section{Další zdroje}

Zákon č. 256/2004 Sb., o podnikání na kapitálovém trhu, ve znění pozdějších předpisů.

KASERER, CH., SCHIERECK, D. (2007): Going Public and Being Public - A Global Comparison of the Impact of the Listing Decision on the Cost of Capital [online]. Dostupné z: http://deutscheboerse.com/dbag/dispatch/en/kir/gdb_navigation/listing/2 0_Going_Public [cit. 2009-02-14].

RITTER, J.R. (2007). Some Factoids about the 2006 IPO Market [online]. Dostupné z: http://bear.cba.ufl.edu/ritter [cit. 2007-10-02].

OXERA. (2006). The cost of raising capital: An international comparison [online]. Dostupné z: http://www.oxera.com/cmsDocuments/Agenda_July\% 2006/Cost $\% 20$ of $\% 20$ raising\%20capital.pdf [cit. 200708-27].

WELCH, I. (2006). A First Course in Finance [online]. Dostupné z: http://welch.econ.brown.edu/ book/ [cit. 2006-08-22].

AAA Auto. (2007). Prospectus [online]. Dostupné z: http://www.aaaauto.cz/cz/articles.php?c=11 [cit. 200902-14].

ECM Real. (2006). Prospekt emitenta [online]. Dostupné z: http://www.ecm.cz/cs/download/ korporatni-dokumenty/prospekt-eminenta-en.pdf [cit. 2009-02-14].

ECM Real. (2006). Výroční zpráva 2006 [online]. Dostupné z: http://www.ecm.cz/cs/download/vyrocnizprava-2006.pdf [cit. 2009-02-14].
Ernst \& Young. (2008). Growth during economic uncertainty: Global IPO Trends Report 2008 [online]. Dostupné z: http://www.ey.com/global/content.nsf/ International/SGM_IPO_Trends_2008 [cit. 2008-06-02]. Nasdaq. (2007). Glossary [online]. Dostupné z: http://ir.nasdaq.com/glossary.cfm?FirstLetter $=\mathrm{i} \quad$ [cit. 2007-09-15].

NWR. (2008). IPO Prospectus [online]. Dostupné z: http://media.corporate-ir.net/media_files/irol/22/

221913/reports/largo_prelim_oktp_prospectus_70101t 09_cnb.pdf [cit. 2009-02-14].

Pegas. (2006). Prospectus [online]. Dostupné z: http://www.pegasas.cz/Data/files/investori/Vyrocni\%2 0zpravy/VZ06_PEGAS_NONWOVENS_SA.pdf [cit. 2009-02-14].

Pegas. (2006). Výroční zpráva 2006 [online]. Dostupné $\mathrm{z}: \quad \mathrm{http} / / / \mathrm{www}$. pegasas.cz/Data/files/investori/ Vyrocni\%20zpravy/VZ06_PEGAS_NONWOVENS SA.pdf [cit. 2009-02-14].

U.S. Securities and Exchange Commision. (2007). Complaint [online]. Dostupné z: http://www.sec.gov/litigation/complaints/complr1732 7.htm [cit. 2007-09-15].

VGP. (2007). Prospekt společnosti [online]. Dostupné z: http://www.vgp.cz/File/Prospekt-(EN).pdf [cit. 200902-14].

Zentiva. (2004). Prospekt emitenta [online]. Dostupné z: http://www.zentiva.cz/download/prospekt/U47380Apr ospekt.pdf [cit. 2009-02-14].

Zentiva. (2004). Výroční zpráva 2004 [online]. Dostupné z: http://www.zentiva.cz/download/annual_reports/ 2004/vz_cz.pdf [cit. 2009-02-14]. 
